\title{
HISTORY OF NIGERIA LAND USE ACT (AN OVERVIEW)
}

\author{
${ }^{1}$ Abatan, Stephen, ${ }^{2}$ Musibau Lawal, ${ }^{3}$ Bankole, Omolara, ${ }^{4}$ Babarinde Racheal. \\ ${ }^{1}$ Department of Urban and Regional Planning \\ ${ }^{2,3,4}$ Department of Estate management \\ Federal Polytechnic, Ede, Osun State, Nigeria
}

\begin{abstract}
The 1978 Land Use Act has a provision that vests ownership of Nigerian land in state/public sector management (LUA). Injustice, loss of land market, lack of fairness, transparency, and inaccessibility of land to the urban/rural poor have all plagued the LUA's implementation over the years. As a result, the critiques vary from an insufficient payment of compensation to the State's improper application of the LUA's requirements, as well as the isolation of $L G$ councils and the urban poor in the execution of the LUA. These comments are supported by the physical inspection and contact with stakeholders in the studied area's land rights. These comments are supported by the physical inspection and contact with stakeholders in the studied area's land rights. The LUA has been proven to be too complicated for the average person to understand, to be exceedingly expensive and oppressive, and to be geared toward governmental needs. The study's goal is to examine present methods in public sector land management in Minna, Nigeria's Niger State, and to come up with a feasible and effective solution to the problems. Respect for existing property rights, access to financing markets, and a favorable policy climate are all recommended for success. The fiscal feasibility of the current government's land reform agenda in Nigeria must be considered.
\end{abstract}

Keywords - Land management, Land tenure, Nigeria, Ownership, Urban poor

\section{INTRODUCTION}

Nigerian land policies, which have a long and illustrious history, include the traditional land tenure system, statutory land law (Southern and Northern protectorates), and the Land and Native Rights Proclamation 1910. However, due to their shortcomings and inability to meet demand, the government promulgated another land policy instrument on March 29, 1978, known as the Land Use Act (LUA). The LUA has repealed the several state land laws that control the country's land tenure structure. The LUA was formed with the goal of unifying land policy across Nigeria and eliminating land speculation in order to defend the rights of all Nigerians to land. It is in the public interest of all Nigerians to be able to use and enjoy land in the country, as well as the natural fruits that grow on it, in sufficient quantities to feed themselves and their families. Despite these goals, the LUA still has certain flaws, which will be discussed in this paper.

In Nigeria, land policy is inextricably linked to government demands and development. Housing production for civil officials, the ability of metropolitan areas to grow into rural areas, and the ability to exploit property without adequate compensation have all been influenced by land policy. Until the LUA, all previous land regulations were limited to certain areas, mostly in the north and south. Land was not held by individuals in old civilization; rather, it was vested in the group, extended family, and village or community. The community Chief assigned land on a freehold basis. Individual ownership was introduced during the colonial period, particularly in Lagos, and two types of land tenure emerged: individual and communal land tenure. Individual ownership was prohibited under the LUA, and the state governors took over as the land's governing authority, replacing the chief, family head, or emir.

This was done, at least in theory, to make land acquisition by the government easier for urban expansion: to make ethnicity less of a factor in land ownership in urban areas, as indigenous groups often controlled land in older urban areas; to encourage non-indigenous people to have access to land; and to reduce land speculation by limiting the amount of land owned by indigenous people. The LUA calls for the formation of Land Allocation Committees to distribute land through the issuance of Certificates of Occupancy. In principle, the LUA aimed to split up big land holdings, facilitating the transfer of property for housing construction and encouraging the restoration of older indigenous communities in key commercial sites in city centers, but it failed to achieve these goals in practice. Traditional authority continue to have power over the property and typically refuse to cede it, and the LUA has had little effect on land speculation or hoarding. While the LUA appears to be a decent idea on paper, according to Okolocha (1980), the strong have exploited the system, the state lacks the desire to execute it, and the principles have not been followed in general. 


\section{International Journal of Engineering Applied Sciences and Technology, 2021 \\ Vol. 6, Issue 5, ISSN No. 2455-2143, Pages 207-219 \\ Published Online September 2021 in IJEAST (http://www.ijeast.com)}

Attempts to regulate and manage urban expansion, on the other hand, are a prominent issue in Nigerian development. The Nigerian Institution of Estate Surveyors and Valuers debated and agreed at several fora that the following policies will set an agenda for planned and orderly urban land management/growth within a social justice framework: (1) the need for a review of the present LUA, as well as coordination of urban planning activities across government levels and agencies; (2) the need to create a national land registry and urban cadastre plan that links economic planning to regional balance and physical planning; (3) the need to promote the development of small and mediumsized cities as a means of reducing regional inequalities and the trend toward primary dominance; (4) the need to encourage more indigenous housing designs that use local building materials. (5) to use a site and services policy, in which the government provides physical infrastructure services to low-income housing residents who rehabilitate or improve existing housing rather than relying solely on public housing; and (6) to remove the existing LUA from the 1999 Constitution and make it more proactive in facilitating land alienation for development. (7) Facilitation of traditional layout designs and ownership with land titles that could motivate credit facilities, reducing traditional ownership restrictions that inhibit urban rehabilitation and peripheral urban development and producing a more efficient land system through facilitation of traditional layout designs and ownership.

Many writers, including the researcher, believe that land policy is an important element of any country's sociocultural framework. It includes the creation of laws, guidelines, strategies, and methods for managing land in the country's body politic. It is legally owned. Land policy, as defined by Umeh (1983), is a collection of rules, principles, objectives, or a course of action relating to land ownership, land development, and land resource exploitation. Umeh (1983) specified eighteen (18) land policy objectives, including: 1, social justice; 2 , social welfare; 3 , economic efficiency; 4, economic livelihood; 5, political stability; 6 , social cohesion; 7, cultural identity; 8, environmental viability; 9, external influence (social, economic, spiritual, political, cultural, and so on); 10, self-sufficiency or independence; 11, national unity; 12, self-renewal; 13, continuity; 14, territorial integrity 15 , conservation of natural resources; 16, rapid development; 17, revolutions or evolutions; and 18, social insurance

\section{AIM AND OBJECTIVES}

The primary goal of this article is to evaluate and debate the significance of land policy in Nigeria's economic growth. While the goals are as follows:

1. Identify/analyze the LUA's flaws

2. Examine the LUA's function in practical land accessibility for development in the Minna urban area
3. Propose a solution/recommendation for achieving the new land management trends.

\section{STATEMENT OF PROBLEM}

In recent years, Nigeria has experienced social and economic difficulties related to land usage as a result of population pressure, urbanization, and socioeconomic expansion. Many people are relocating from rural to urban regions where contemporary services are accessible as a result of urbanization; population pressure in cities and towns has created a unique challenge of residential housing. Congested metropolitan areas require growth, yet land on which this expansion may be accomplished is limited. Land has become a valuable commodity, and it is no longer the ordinary land that Africa has traditionally regarded as a gift from nature to people. Prior to the LUA, the law's provision of a piece of land to each member was ignored. Because there is no specific provision in the LUA that repeals prior land laws on the same subject matters, it works alongside them. "Lands in the Northern States must continue to be administered in line with the provisions of the Land Tenure Law unless "other arrangements are established in that respect," says Section 4(a) of the LUA. Non-natives are prohibited from gaining title to land that is subject to customary law under this rule.

Individuals and groups seeking property under the LUA for residential, commercial, industrial, agricultural, or other uses face lengthy government bureaucratic processes and are frequently susceptible to corruption.

Any ownership that does not have the approval of the state or local government is considered unlawful. A case in point is the current government in Niger state, where even LG titles are ignored and viewed as unlawful, despite the fact that Certificates of Occupancy (C. of O.) are sometimes given in line with the LUA as is normal. Residential areas of the 'Unguwan daji' Minna old town settlement have been ear-marked for demolitions, and residents have been given only seven (7) days to remove their belongings or face forced eviction/demolition, simply because the over 50 houses ear-marked for demolitions share boundaries with public schools. The notices were sent out on the same day that the legitimate title holders were notified. Who is encroaching on whose land/rights, one may wonder? Is it the inhabitants who have their wards/children in the neighborhood schools, with a C.of O. signed by the Governor/LG Chairman in the case of customary title holders who pre-date the LUA, or is it forcible acquisition for the 'public benefit' without compensation or due process? This, regardless of one's position on the rule of law, clearly contradicts the principles of effective municipal government. Even though a renter in possession of the premises (home) is entitled to three (3) to six (6) months' notice to relocate, what more is a house owner with his wife and children entitled to? Similarly, the Federal Capital Territory (FCT) of Abuja has significant problems, 


\section{International Journal of Engineering Applied Sciences and Technology, 2021 \\ Vol. 6, Issue 5, ISSN No. 2455-2143, Pages 207-219 \\ Published Online September 2021 in IJEAST (http://www.ijeast.com)}

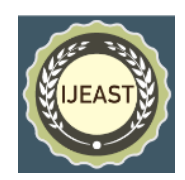

according to Iro (2008), AGIS-GM, who said that over 6000 C. of Os from recertification had still to be manufactured and distributed. And around 150,000 C.of Os from the regularization of titles in the Area Councils, plus 12,000 C.of Os from the sale of Federal Government Houses, 4,000 C.of Os from Federal Authority plots, and 12,000 C.of Os from the sale of Federal Government Houses. He also emphasized the significant demand for huge amounts of data from courts considering over 750 land-related lawsuits, including 2,400 revocations and 1,700 duplicate allocations. This is the result of LUA's negative implementation. Furthermore, according to Nuhu (2006b), compensation estimated in 1990 for the acquisition of a site for the University of Abuja had not been paid as of 2006, when the research was performed. Nuhu (2007a) recognized that the preceding Governing Public Land Acquisition and Compensation Payment in Nigeria has resulted in conflicts, lapses, and disagreements. Claimants whose rights have been revoked are invariably on the losing end of the game, and they are almost always in a worse position than they were before the revocation. As a result, the compensatory goal has been defeated.

The insufficiency of the compensation payable owing to the LUA's statutory method of valuation has been investigated, and Nuhu (2007b) has suggested that the LUA be removed from the Federal Republic of Nigeria's Constitution. He suggests that you: Professionals should also be involved in the development of an effective National Land Policy for Nigeria, as it was noted that the lack of any LUA implementation guidelines has made it difficult for the various States to have a uniform approach to the implementation process, which is contrary to the main goal of the LUA, in addition to operational and bureaucratic issues, and institutional capacity. The purpose of this study is to provide responses to the following research questions: i. Do people have the legal right to acquire land in the state? ii. Does the Governor have complete authority over the revocation and allocation of land to state residents? iii. Is the state-owned land being appropriately managed? iv. Are there any flaws in Nigeria's land policy, such as the Land Use Act?

\section{THEORETICAL AND CONCEPTUAL FRAMEWORK}

The United Nations Conference on Human Settlements [Habitat 1], held in Vancouver from May 31 to June 11, 1976, declared unambiguously the UN's official land policy: 'Land cannot be regarded like any other asset, managed by individuals and subject to market forces and inefficiencies.' Private land ownership is also a key tool for wealth accumulation and concentration, contributing to social inequality; if left uncontrolled, it may become a major impediment to development planning and execution. Land must be used in the interests of society as a whole in order to provide good housing and healthy circumstances for individuals. As a result, public land regulation is required.

'Public ownership and effective control of property in the public interest is the single most essential method of...achieving a more equal distribution of the benefits of development while ensuring environmental consequences are recognized,' the Report noted in its recommendations. However, public land ownership cannot be justified in and of itself; it can only be justified if it is used for the general benefit rather than to preserve the interests of the already privileged.'

The UN's land policy should contribute to correcting individuals in charge of the African State's management's erroneous perception. Which is it: a valid right of the people over their natural resources is to fight for the return of their traditional rights to their land, its resources, and their management? However, the state's reorientation toward the restoration of indigenous peoples' rights to land and resources has been greeted with strong opposition, owing to the state's and local/foreign capital's materialist interests in land and resources. Land policy is a course of action chosen and implemented by its area of authority in relation to land usage or rights over the land because it is expedient and advantageous to do so. Its goal is to achieve a balance of interests between the government, the land-owning class, and the landless class. Five broad land policy goals have been defined within the framework given by this master aim (Barlowe, 1985).

i. A broad distribution of ownership, operatorship, occupation, and usage rights among citizens who want to utilize them.

ii. Appropriately sized and productive-potential land holdings to maximize production prospects.

iii. Orderly and fair operating arrangements that promote land-resource efficiency.

iv. Arrangements that provide land operators with economic possibilities, security, and stability, as well as

v. Arrangements that lead to land resource development and conservation

In the meanwhile, it must be understood that the list is not exhaustive, and that individual objectives may clash. Priorities must be allocated to individual goals from time to time to indicate the direction in which programs should proceed when two or more goals are in conflict. The agricultural system that a national land policy promotes, or at the very least enables, has an impact on the environment and the lives of farming people. It defines the range of permitted freedom of choice in the use and occupancy of land in farming systems; it is the matrix of choice for the use and occupancy of land in farming systems, conservation practices, and the intensity of exploration in usage. The question is whether to let market forces and personalized tenure to rule or to intervene in market or free enterprise solutions to land ownership and usage issues (Parsons, 


\section{International Journal of Engineering Applied Sciences and Technology, 2021 \\ Vol. 6, Issue 5, ISSN No. 2455-2143, Pages 207-219 \\ Published Online September 2021 in IJEAST (http://www.ijeast.com)}

1982). Land policy essentially consists of two components: subtle strategy and land reforms. Subtle methods govern the exercise of property and land use rights. Town planning regulations, public health edicts, compulsory acquisition rules, residential tenancy laws, and so on. Prior to LUA, Nigeria had two land tenure systems: a type of freehold system in private properties, where people, families, and communities owned and controlled property, and a leasehold system in the north, which was given by either customary law or the government.

This approach ensured that governments were involved and relevant anytime land was needed. The existing compulsory acquisition law did not aid the government in any way and provided no provision for supporting private individuals who wanted land to build a house for themselves and their family. Furthermore, the government could not compel a private entrepreneur to buy property for the purpose of establishing a successful enterprise, the lack of which would have a severe impact on the nation's economy. Furthermore, while the government might forcefully take property and improvements on it for public use, the fact that individuals own the land, whether unoccupied or developed, creates psychological barriers and strains the relationship between the government and the landowner. The LUA's most significant accomplishment is that it has harmonized Nigeria's land tenure laws. It has repealed the numerous state land laws that governed the country's land tenure structure. It has made a lawyer's and a court's job simpler in deciding the applicable land law, despite the fact that the expense of litigation is expensive and beyond of reach for the average person, as well as the delay in dispensing justice, which may be highly inconvenient.

'Nuhu (2007) examined the process of land acquisition and compensation within the framework of the LUA in the development of the new Capital Territory Abuja, in Nigeria, and reveals that the existing provisions of the law cannot adequately compensate dispossessed land owners,' according to Viitanen and Kakulu (2008). It relates the difficulties surrounding compensation to the provisions of the LUA's statutory procedures of valuation, and recommends that statutory valuation systems in Nigeria require revision. In Nigeria, Kakulu (2007) examined 'valuation process' difficulties in the evaluation of compensation in forcible land acquisition. The process of land acquisition and compensation for the building and development of oil and gas production infrastructure in the Niger Delta area was specifically mentioned. The analysis was done in the context of assessing and resolving conflicts. Some of the causes that contribute to the current problem in the Niger Delta area are said to include the assessment and payment of inadequate compensation to expropriated land owners. In contrast to other types of valuation, compensation valuation can be scrutinized by third parties such as civil society and human rights organizations if there is a public outcry of insufficiency, and rules are necessary to safeguard valuers.

In terms of accountability, compensation assessment is required to meet not only professional valuation standards, but also constitutional and international obligations for just, fair, sufficient, and equitable pay. Inadequate compensation assessment and payment are blamed on a lack of transparency, a lack of professional standards, weak governance, and an underlying fabric of corruption, according to the report.

\section{LAND ALLOCATION PROBLEMS}

Land problems are divided into five categories by Denman (1962): i. Allocation of land resources; ii. Redistribution; iii. Restraints on absolution; iv. Security investment and private gain; and v. Taxation. Duration, compensation, and alienation are the three most important aspects of the security dilemma. An inferior interest's duration may be dependent, or a combination of the two deaths may constitute the condition that ends the life interest's duration.

It is critical to examine the impact of land scarcity and challenges of access to land while attempting to address poverty issues, as this has been a component of human life since time immemorial. Duration, compensation, and alienation are the three most important aspects of the security dilemma. An inferior interest's duration may be dependent, or a combination of the two deaths may constitute the condition that ends the life interest's duration. It is critical to examine the impact of land scarcity and challenges of access to land while attempting to address poverty issues, as this has been a component of human life since time immemorial. Land rights are social norms that govern how benefits derived from certain uses of a piece of land are distributed. A variety of arguments justify the granting of such rights by the government. First, the high fixed cost of building and maintaining the institutional infrastructure required to create and preserve property rights favors public provision, or at the very least regulation. Second, the advantages of being able to swap land rights will only be realized if those rights are standardized, controlled, and can be simply and independently confirmed. Finally, without centralized provision, homeowners and business owners will be forced to spend resources to defend their property claims, such as through guards, fences, and other means, which is not only socially wasteful but also disproportionately disadvantages the poor, who will be the least able to afford such expenditures (Deininger, 2005)

As a result, according to Mabogunje (2005), the idea of land has evolved over time to cover at least seven diverse meanings, including land as 1 . space 2 . nature 3 . a component of production.4. Consumable commodities. 5. A geographical feature. 6. Property and 7. capital 


\section{International Journal of Engineering Applied Sciences and Technology, 2021 \\ Vol. 6, Issue 5, ISSN No. 2455-2143, Pages 207-219 \\ Published Online September 2021 in IJEAST (http://www.ijeast.com)}

\section{CONTINUUM OF LAND RIGHTS}

Except for transfer, abandonment, death, and expulsion from the society, rights are permanent and can be established by oral proof. It is unlawful to occupy unoccupied property without legal permission, and anybody who does so risks being evicted. Because the chief is a constitutionally recognized entity, this power may be a chief's authorization for customary land (Mulolwa, 2002). A portion of village land is considered a birth right (Chileshe, 2005, citing Parsons, 1985), and migratory workers are entitled to land if they return to the community. UN-Habitat (2004) and Payne (2000) define land rights and tenure regimes as a series of continuums (see Fig. 1). The following rigorous continuum of land rights (with increasing formality or legality) was generated from these lists by Van As Peren and Zevenbergen (2006): Statutory leasehold; Statutory - freehold; Illegal; Informal; Customary. They emphasized that the continuum should only be used as a starting point for legal analysis. Due to user activity or legal action, the legal position may change. In any tenure system, a user action might be the transfer or subdivision of any land right. This type of user behavior might be unlawful, unofficial, or legal. Legal measures are taken in response to the passage of new legislation or directives that affect tenure security.

Adverse possession or anti-eviction measures come to mind. These acts will undoubtedly have an impact on the relevant rights within the continuum, and hence on the amount of tenure security. The existence of an agreement distinguishes illegal and informal land rights. There is no agreement presumed to exist between right holders in the event of an unlawful right. The agreement might be either oral or written. However, such agreements may not have a legal foundation.

Land access is essential for human housing, food production, and other economic activity, including that of companies and natural resource users of various types. Secure land rights encourage individuals to invest in better housing and the land itself, as well as providing access to public services and financing. Property rights can be made up of a variety of factors. These rights include the ability to:

- Occupy, enjoy, and use;

- Cultivate and utilize effectively; and

- Restrict or exclude others.

- Inherit and bequest

- Develop or enhance

- Rent and sublease

- Profit from rising property values or rental income.

Land rights that are recorded can clearly assist other rights and possibilities. These rights include civic and political engagement, as well as access to basic services and finance. Land, according to Fortune-Ebie (2007), is money; land is credit subject to land titling, registration, and secured tenure. Land policy is significant because it is anticipated to improve:
- Investments, credit, and productivity all contribute to economic growth.

- Poverty eradication: subsistence agriculture, market surpluses, and socioeconomic status

- Governance: democratic foundations, decentralization, lack of disputes, and accountability

- Environmental sustainability: efficient land use, externalities integration, and state land management

The validity of land agencies and land administrators is generally acknowledged by citizens; land agencies serve all people, including the weak as well as the strong; and land agencies serve all citizens, including the weak as well as the strong, as stated by Nuhu (2008c). Land agencies provide services that are tailored to the needs of their clients, such as the type of the services and their accessibility; the services' outcomes are consistent, predictable, and unbiased. The services are delivered in a timely, effective, and knowledgeable manner. Integrity, openness, and accountability characterize the services offered. However, several problems exist, particularly in Nigerian institutional frameworks, which have an impact on state and public land management and may be harmful to the implementation of effective land policy.

\section{CHALLENGES IN NIGERIAN INSTITUTIONAL FRAMEWORKS FOR STATE AND PUBLIC SECTOR LAND MANAGEMENT}

The development of the Nigerian economy, owing mostly to the discovery of oil, has resulted in a significant number of individuals being wealthy enough to construct nicer homes and manage big farms. Heavy and big industries have also been created, resulting in increased demand for land. The federal government formed twelve states at first, and then nineteen states (19), which increased the need for more land in some areas, notably the new state capitals. Roads, offices, an airport, parks, and other institutions were constructed as necessary infrastructure. In general, the LUA was created in response to litigation issues and the concentration of land in small hands. Other goals, however, include:

- Land redistribution as a source of productivity

- To improve government implementation of development programs (or projects) by having control over land against land speculators (i.e. management controls and against speculators)

- Allowing every citizen to enjoy land for the rest of their lives and allowing anybody to purchase land in any region of the country, regardless of where they are from, whether they are from the south or the north.

- To guarantee effective land use rather than homogeneity. In order to derive the greatest possible profit from the land. - To unify the pleasure of land ownership. 


\section{International Journal of Engineering Applied Sciences and Technology, 2021 \\ Vol. 6, Issue 5, ISSN No. 2455-2143, Pages 207-219 \\ Published Online September 2021 in IJEAST (http://www.ijeast.com)}

Why To eliminate the better disputes that land is known to generate, which may sometimes end in the loss of lives and limbs.

- To streamline and simplify the country's land management and ownership.

- To allow the government to make planning and zoning programs for specific land uses easier.

- To integrate and simplify all of Nigeria's diverse land tenure regimes.

- Ensure that all Nigerians living in each state and organization have access to urban land for all purposes.

- To keep the actions of land speculators to a bare minimum. system.

Following an examination of the LUA and its particular weakness or faults that prevent it from fulfilling the aforementioned objectives, (Adu, 1998) discovered the following shortcoming of LUA:

i. In certain states, there are moderate delays in land allocation and availability for occupation, i.e. there are needless delays on the part of the Governor and Local Government in allocating land to those who request for it.

ii. Delay in processing application for approval of land transaction, i.e., due to the length of time, there are unnecessarily long delays in the processing of the application. Delays in the processing of applications might occur when applicants refuse to give the individuals in charge money or when the Governor or the Local Government takes too long to approve the document for a property transaction.

iii. State-imposed exorbitant charges or fees for administrative services, etc. Another flaw or fault of LUA is the excessive charges or fees requested by those who do not regard the job as their own but rather as something imposed on them by others. Many people who refuse to pay have run into significant difficulties.

iv. The exercise of authority by the relevant authorities in an arbitrary manner.

v. Inadequate compensation for landed assets taken by the government under the LUA.

The compensation paid to persons whose Right of Occupancy has been revoked for public reasons contains several flaws and injustices. Some rights of occupancy are gained by force, and the compensation given is insufficient to compensate for the value of the land's unexhausted improvements.

a. Some state governments have failed to follow the LUA's provisions on land administration. Every other land-related policy or regulation is forbidden from the moment it is enacted, and the relevant local authority is responsible for administering and managing land policy. One of the goals of the Land Use Act is to provide people access to land, however the opposite is true. Many Nigerians are severely restricted in their access to land in a variety of ways, including funding, application, approval, and allocation, whereas the wealthy have unrestricted access. One of the LUA's goals has been defeated as a result of this.

For example: (a) some states refuse to form/reform the Land Use and Allocation Committee (LUAC); (b) some use only civil servants/political appointees as members of the LUAC, ensuring the role of both accuser and judge; and (c) core delegated powers to the Commissioners for Lands and Housing without due regard for tenure/security issues.

In 2002, the Expert Group Meeting on Urban Indicator defined tenure security as "the right to all people and groups to adequate governmental protection against forced evictions." Forced eviction is defined as "the permanent or temporary removal against their will of individuals, families, and/or communities from the homes and/or land which they occupy, without the provision of, and access to, appropriate forms of legal or other protection" under international law (to which Nigeria is a signatory).

Land is a crucial component in attaining MDG 11: "Cities without Slums." This goal was recently highlighted in the UN 2005 World Summit, along with other significant pledges. Land, particularly procedures linked to land administration, is an important factor for sustainable urbanization in UN-activities. HABITAT's Forced evictions, unrecognized rights and the difficulties in exercising them (raising the degree of marginalization from the decisionmaking process), and impediments to using property as a source of income or collateral to get credit are all major concerns.

\section{METHODOLOGY}

The investigations concentrated on the key players in urban land administration and management in Minna, the Niger State Capital, including the governmental sector, commercial sector, real estate developers, and traditional land owners. The literature evaluations were based on literary reviews from a variety of periodicals, journals, and papers presented at international conferences. Questionnaires were utilized to collect data and were sent to randomly chosen stakeholders in Minna's urban land regions. Field visits/discussions were used in equal measure. Investigating techniques modified from Brasselte, Gaspart, and platteau (1998) addressed questions on manner of acquisition, rights of transfer and usage, land improvements made, kind of document possessed, and incidence disagreement; the collected data were compared on the research area's urban poor.

\section{STUDY AREA}

Nigeria is one of the wealthiest countries in Sub-Saharan Africa, yet poverty is rampant at the family level due to widespread corruption in many areas, including land management. Nigeria has a geographical mass of roughly 924,768 square kilometers, which is somewhat larger than 


\section{International Journal of Engineering Applied Sciences and Technology, 2021 \\ Vol. 6, Issue 5, ISSN No. 2455-2143, Pages 207-219 \\ Published Online September 2021 in IJEAST (http://www.ijeast.com)}

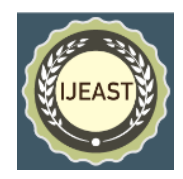

the state of California in the United States. It has an 853kilometer-long coastline, as well as a Federation comprising 36 states and the Federal Territory of Abuja. According to the 2006 Census, the city has a population of 144.7 million people, a 2.4 percent annual growth rate, and more than 250 ethnic groups. Nigeria is located on the continent's west coast, with its shoreline to the south and Niger and Chad to the north. To the west is Benin, while to the east is Cameroon. The Nigerian economy had 51.320 US \$ billion in external reserves in 2007, compared to 7.681 US $\$$ billion in 2002, and a market capitalization of 82.1 US $\$$ billion in 2007, compared to 6.2 US \$ billion in 2002, while inflation was lowered to 5.7 percent in 2007 , compared to 12.2 percent in 2002.

Nigeria is urbanizing at a breakneck speed. Over the previous three decades, the urban population has grown at a rate of around 5.8\% each year. According to the Federal Ministry of Housing and Urban Development (2003), this is one of the world's fastest growing cities, owing mostly to migration from rural to urban regions.

\section{NATURE OF TENURE SYSTEM AND RIGHTS IN THE STUDY AREA OF MINNA.}

Despite huge external reserves, the demand for infrastructure, basic services, and housing in expanding urban centers, Nigeria's rapid urbanization has not only progressively complicated and exacerbated interrelated human settlements and environmental problems, but it has also greatly accelerated poverty. The UN's Millennium Development Goal of improving the lives of 100 million slum dwellers in Africa by 2020 has brought concerns such as high unemployment, sanitation, waste management, transportation, crime, and social strife to the forefront and worldwide attention. Minna is a Gwari (Gbagyi) town in Nigeria's middle belt, located 9037 degrees north of the equator and 6033 degrees east of the Greenwich meridian. The settlement is located to the north-west of Abuja, the Federal Capital Territory. Minna grew in prominence as an administrative center throughout time, and its role as a rail junction drew additional investment and people. Minna became the state capital of Niger State in February 1976.

The current town is spread out along the major spin from Chanchaga in the south to Bosso in the north, where the University is located. Minna had a total population of 201,429 people according to the 2006 census (provisional findings) (105,803 males and 95,626 females). The State Government controls the ownership of land and other land resources inside the urban area. Such control is exerted and administered on behalf of the whole state's people. Individuals who are implicated can only maintain a leasehold interest for a set period of time. The LUA and other underlying tenure systems in the area have established certain similar concepts. Traditional chiefs, whose power over land stems from the Native Land Law of 1962, continue to play a dominant role in several Minna villages, such as Bosso, Fadikpe, Barikin-Sale, Dusten-Kura, Kpakungu, Maitumbi, Unguwan-Kaje, Shango, and other locations. In these districts of Minna, people receive land through traditional chiefs, who account for around 55 percent, 45 percent through state allocation, and 10 percent through transfer.

Minna access to land is relatively unaffordable in relation to income generation for the urban poor, particularly from state allocations, which is usually very expensive, cumbersome, and beset by administrative bottlenecks due to the relative peace enjoyed in Minna and its proximity to F.C.T., Abuja. These factors influenced the decision to buy land the conventional method, which is both cheaper and faster. Where private property tenure is in place, market pressures and commercial transactions are key determinants of land transfers, and traditional practices of the "Gbagyis" have recently gained clout; access to land is largely achieved through purchase based on land value.

Except for the rights to public interest, all rights are permanent. Traditional customary institutions are being straightened as they continue to win court judgments in their favor against the state and are increasingly being acknowledged by people who perceive them as a costeffective and safe method to shelter.

Table -1 NUMBER OF APPLICATION FOR LAND ACQUISITION IN MINNA FROM 2013 to 2019

\begin{tabular}{|l|l|l|l|l|l|l|l|l|}
\hline \multicolumn{1}{|l|}{ TYPE OF USE } & \multicolumn{6}{l|}{ YEAR } \\
\hline & 20 & 20 & 20 & 20 & 20 & 20 & 20 \\
13 & 14 & 15 & 16 & $\begin{array}{l}\text { TOT } \\
17\end{array}$ & $\begin{array}{l}\text { AL } \\
19\end{array}$ \\
\hline $\begin{array}{l}\text { Residen } \\
\text { tial }\end{array}$ & $\begin{array}{l}12 \\
16\end{array}$ & $\begin{array}{l}71 \\
8\end{array}$ & $\begin{array}{l}83 \\
2\end{array}$ & $\begin{array}{l}10 \\
21\end{array}$ & $\begin{array}{l}77 \\
6\end{array}$ & $\begin{array}{l}70 \\
3\end{array}$ & $\begin{array}{l}63 \\
9\end{array}$ & 5905 \\
\hline $\begin{array}{l}\text { Comme } \\
\text { rcial }\end{array}$ & $\begin{array}{l}12 \\
0\end{array}$ & $\begin{array}{l}10 \\
1\end{array}$ & $\begin{array}{l}12 \\
5\end{array}$ & $\begin{array}{l}10 \\
2\end{array}$ & 52 & 37 & 43 & 580 \\
\hline $\begin{array}{l}\text { Industri } \\
\text { al }\end{array}$ & 3 & 1 & 3 & 2 & 1 & 1 & 4 & 15 \\
\hline $\begin{array}{l}\text { Agricult } \\
\text { ure }\end{array}$ & 11 & 13 & 13 & 9 & 10 & 7 & 3 & 66 \\
\hline $\begin{array}{l}\text { Religiou } \\
\text { s }\end{array}$ & 8 & 5 & 2 & 4 & 7 & 5 & 5 & 36 \\
\hline Total & 13 & $\begin{array}{l}83 \\
8\end{array}$ & $\begin{array}{l}97 \\
5\end{array}$ & $\begin{array}{l}11 \\
38\end{array}$ & $\begin{array}{l}84 \\
6\end{array}$ & $\begin{array}{l}75 \\
3\end{array}$ & $\begin{array}{l}69 \\
4\end{array}$ & 6602 \\
\hline
\end{tabular}

Source: Department of Lands, Survey and Town Planning, Minna 2021

Table -2 NUMBER OF APPROVED APPLICATION FOR LAND ACQUISITION FROM 2013 to 2019

\begin{tabular}{|l|l|l|l|l|l|l|l|l|}
\hline \multicolumn{3}{|l|}{ TYPE OF USE } & \multicolumn{3}{l|}{ YEAR } \\
\hline & 20 & 20 & 20 & 20 & 20 & 20 & 20 & TOT \\
& 13 & 14 & 15 & 16 & 17 & 18 & 19 & AL \\
\hline Residen & 85 & 68 & 79 & 98 & 73 & 70 & 63 & 5363 \\
tial & 0 & 0 & 0 & 0 & 0 & 3 & 0 & \\
\hline
\end{tabular}




\begin{tabular}{|l|l|l|l|l|l|l|l|l|}
\hline $\begin{array}{l}\text { Comme } \\
\text { rcial }\end{array}$ & $\begin{array}{l}11 \\
0\end{array}$ & 94 & $\begin{array}{l}11 \\
0\end{array}$ & 98 & 48 & 36 & 40 & 536 \\
\hline $\begin{array}{l}\text { Industri } \\
\text { al }\end{array}$ & 3 & 1 & 2 & 1 & 1 & 1 & 3 & 12 \\
\hline $\begin{array}{l}\text { Agricult } \\
\text { ure }\end{array}$ & 10 & 12 & 11 & 7 & 8 & 6 & 2 & 56 \\
\hline $\begin{array}{l}\text { Religiou } \\
\text { s }\end{array}$ & 8 & 4 & 2 & 3 & 6 & 5 & 5 & 33 \\
\hline Total & $\begin{array}{l}98 \\
1\end{array}$ & $\begin{array}{l}79 \\
1\end{array}$ & $\begin{array}{l}91 \\
5\end{array}$ & $\begin{array}{l}10 \\
89\end{array}$ & $\begin{array}{l}79 \\
3\end{array}$ & $\begin{array}{l}75 \\
1\end{array}$ & $\begin{array}{l}68 \\
0\end{array}$ & 6000 \\
\hline
\end{tabular}

Source: Department of Lands, Survey and Town Planning, Minna 2021

Table 1 illustrates the number of land acquisition applications filed in Minna between 1999 and 2005 for various uses, while Table 2 shows the degree of approvals given to such applications.

Table 1 shows that between 1999 and 2005, 5363 residential land use applications were accepted and 536 commercial land use applications were authorized out of a total of 5905 land purchase applications. Only 12 out of the 15 applications for industrial land use were accepted. In Minna, only 26 applications for agricultural land use and 33 applications for religious land use were approved over a seven-year period.

\section{SUMMARY OF FINDINGS}

According to the research, the LUA is the current land policy in Minna and its surrounds. Land management and administration are handled by the department of lands, survey, and town planning, which has approved 5,363 applications for various land uses over a seven-year period (1999-2005), out of a total population of 201,429 people in Minna. The present land policy in Nigeria (LUA) is obsolete; it has been shown to be full of bottlenecks and harmful to mass house development, as well as cumbersome and out of reach of the average citizen.

\section{NEW TRENDS}

'When executing land management policies, land administration is the process of determining, documenting, and disseminating information regarding ownership, value, and usage of property.' (United Nations/ECE, 1996). While access to land and land-related benefits is a critical component of poverty reduction and economic progress (World Bank 2003). Reforms in the regulatory framework, as well as advancements in titling and registration, will almost certainly have a catalytic effect on land markets. Decentralization and subsidiary planning should be prioritized in strengthening the land tenure system, with a focus on civic involvement and private efforts, as well as developing cross-current or so-called conversation planning between the bottom and top levels. With well-balanced private-public partnerships and proper interrelationships between land policy framework, land information or spatially enabled land administration (such as land tenure, land values, land use, and land development), institutions, capacity building, education and research, and finally services to businesses and citizens, as well as facilitating sustainable development toward a better quality of life

Munro-Faure (1999) proposed that, in the context of sustainable development, this legal framework and administrative structure acts as a control in the environmental/planning context, and as a determinant of land market development, land ownership, and planning/environmental policy in the broader economic context. He went on to say that it has a big influence on market prices and, as a result, on economic decisions about what to do with land.Real estate is a collection of legally recognized land rights. This system of legislative rules and contractual conditions related to a given estate generally contains legal definitions of what defines "real estate ownership." These rules, he believes, generally describe

- the types of real estate that may be held and how they are owned (usually in Constitution, Civil Code, Land Law, Registration Law, etc)

- What are the transactional processes that must be followed? (usually in Land Law, Registration Law, Leasing Law, etc)

- any limitations on usage that may exist (usually in Town and Country Planning Law, Environmental Law, etc)

-What rights may be reserved for the state or the general public? (usually in Civil Code, Land Law, Compensation Law, Taxation Law, etc)

- whether third-party rights may exist (typically in Marriage Law, Inheritance Law, and Probate Law) (etc)

- what contractually connected parties' rights may be (usually in Mortgage Law, Leasing Law, etc)

Developing new land policies, on the other hand, may be a lengthy and complex process. It's much more important if the policies are pro-poor, i.e., if they're meant to help poor people overcome the disadvantages they face in many aspects of land policy. This handbook outlines a course of action. It is not a recipe book, but rather explains a method that can be tailored to the circumstances in each nation and the specific component of land policy that has to be handled. It is based on experience in many developing countries. Many people consider this to be a participatory process since it incorporates a wide range of stakeholders from all sectors of land policy, including civil society and the poor. It is critical to include all of these groups if the policies that arise are to be politically acceptable, technically viable, propoor, and enforceable. In order to keep up with global trends, Nigeria's current administration intends to reconsider its current land policy, and Land Reforms is the 5th point on the 7-Point Agenda of the Federal Republic of Nigeria, which states: "Review the existing Land Laws to ensure equitable use of the Nation's Land Assets for socioeconomic development." 


\section{International Journal of Engineering Applied Sciences and Technology, 2021 \\ Vol. 6, Issue 5, ISSN No. 2455-2143, Pages 207-219 \\ Published Online September 2021 in IJEAST (http://www.ijeast.com)}

Land reform refers to the process of altering and restructuring land tenure regulations and procedures in order to align them with the overall needs of economic growth. Changes in the political, social, and economic positions of many groups in society are involved in the restructuring of these norms and processes. Although there are differing views on the extent and meaning of "Land Reform" (Barlowe, 1958). It has a fundamental meaning that is substantial and purposeful in terms of land tenure. The goal of land reform is to redistribute income and increase equity for peasant farmers.

It refers to the transfer of property rights in land resources for the benefit of poor farmers, landless peasants, and agricultural workers in the traditional sense. The interconnected aspects of productivity and land use equality are the focus of land reform. It's a strategy for affecting structural change in the agricultural sector, such as changing the size distribution of holdings or income distribution (Fabiyi, 1995). (World Bank, 1975; 208) Land reform might take one of the following forms:

i. Land redistribution, whether public or private, to alter land distribution patterns and holding sizes.

ii. Consolidation of separate holdings, resulting in a reorganization of physical control patterns.

iii. Land-ownership and tenural rights changes, with or without physical redistribution of land; and iv. Changes in tenure conditions without altering ownership or transferring land.

In order to carry out the planned land reform in Nigeria, the following modifications are required, according to Munro(1999) Faure's opinion on change: a legislative framework with appropriate requirements, as well as incorporating the systems supported by cadastral infrastructure.

- The Land Tenure System, which protects legal property rights such as titles, mortgages, and easements.

The Land Value System, which assesses land and property values and collects land taxes.

- Land-Use Control System, which allows for precise and comprehensive land-use planning.

- Land Development System, which enables land use modification regulation and execution.

- The real property idea allows for control of land as a legal, fiscal, and physical item in this way.

In his keynote presentation at the Lagos International Housing Conference 2008, Fortune-Ebie (2008) called for "a full review and extensive revisions to this odious Land Use Act, which has strangulated and castrated mass housing construction in Nigeria for the last 30 years." The goal of a successful land policy for Nigeria should be to better the lot of the average land operator while also accelerating dramatic improvements in the country's growth. Its importance will be widely recognized because it should provide the necessary bridge for large segments of the country's population to shift to a position where they can better utilize their available resources, regardless of their social status, in addition to contributing more to national production and sharing more in the bounty of the land. Its potential as a tool for increasing human value and wellbeing, as well as promoting national economic progress, is widely recognized in most industrialized countries across the world.

Land administration systems, in addition to the legislative framework, are the most important tool for implementing land policy. Organizations and methods for surveying, demarcating, and mapping land, documenting land rights and transactions, providing documented proof of land rights, and resolving land disputes and conflicting claims are among them. Land administration systems are typically handled by government-established specialised formal land institutions. Land distribution, documentation, and administration of rights, on the other hand, can be transferred to local, community, or customary authorities, and some services may be provided by the private sector. Because land-related services are accessible to all land users, including the poor and vulnerable, as well as commercial investors, effective, well-adapted land administration systems promote the fulfillment of the widely recognized land policy goals of secure land. If land rights are to be properly protected, land access must be improved, land allocations must be made more equitable, and land needs must be addressed.

- Land administration institutional structures are open to everybody. Rather of using highly centralized systems, these are better supplied in a decentralized manner that may adapt to local demands.

- Up-to-date, comprehensive land information systems that can capture the complexities of existing land occupation, usage, and claims, including overlapping sets of rights. When formal land administration services are given at the local level, they are most successful.

\section{CONCLUSION/RECOMMENDATION}

The study has shown major flaws in Nigeria's current land policy. The organization in charge of land management in Niger State was identified. Poor policy execution, land acquisition and speculation problems, insufficient accessibility to land, inadequate infrastructural facilities and social amenities, among other issues, were cited as challenges in Minna's land administration and management. Certain new trends and methods are proposed to improve land acquisition policy, public involvement, technological infrastructure, the development of government layouts, and the design of excellent urban land policy to reduce administrative bottlenecks. These will go a long way toward ensuring that land is used for living, working, circulation, and enjoyment in Minna in a way that is useful, safe, secure, and comfortable. In particular, the following tactics must be implemented. 


\section{International Journal of Engineering Applied Sciences and Technology, 2021 \\ Vol. 6, Issue 5, ISSN No. 2455-2143, Pages 207-219 \\ Published Online September 2021 in IJEAST (http://www.ijeast.com)}

- Recognizing the complexities of current land markets and expanding on successful procedures. This allows governmental, corporate, and civil society parties to form a variety of fruitful collaborations. The government can encourage and regulate pluralistic land and housing markets, in which a wide range of suppliers compete on an equal footing to fulfill the demands of different segments of the population.

- Encouraging public engagement in a shared vision of how future settlements should be developed. Cities Alliance's 11 City Development Strategies 11 give a framework for creating and implementing such a vision in metropolitan areas.

- Examining the framework of planning and construction rules, standards, and administrative procedures for the processing of new developments, changes of use, transfers, and other similar activities, to ensure that they represent the entire range of local requirements and resources. Many normally law-abiding persons will be forced into illegal developments if official norms and processes impose uncertainty, unreasonable delays, or expenses. A regulatory audit might uncover any restrictions that need to be eliminated or eased to allow for incremental expansion.

- The government's role in the governance and administration of land in Niger State must be reconsidered. Members of the public should be educated on land issues so that they may comprehend the extent and constraints of land usage in general.

- It should promote efficiency and land usage to the fullest extent possible. Access to land for economic and social purposes should be a goal of the policy. The policy should be consistent with other current policy instruments and should be able to integrate effectively with the state's and country's cultural and political systems.

However, land regulations and allocation procedures are not always consistent, and the public discovers that there are a number of options for obtaining authorization and documented evidence of property rights while maximizing opportunities. Claimants who engage in such 'institutional shopping' take advantage of their knowledge and connections with different official and informal agencies and processes in order to acquire access to land. This may create a lot of confusion, and it can lead to conflict between land users who claim various sources of legitimacy, as well as social groupings. It is critical to examine the following factors while drafting or modifying land management and tenure policies.

- The gradual development approach permits individuals in both urban and rural regions to invest what they can when they can, as long as their rights are protected.

- In order to decrease costs and uncertainty in the processing of planning and construction applications, regulatory impediments to affordable and incremental land development must be examined and, if required, modified.
- When correctly managed, housing may be a source of economic development rather than a welfare burden on the economy.

- Similarly, prudent management of rural land development, agribusiness investment, and environment protection may boost employment and promote socially inclusive growth as long as rural people's land rights are protected. Land tenure choices may be tailored to fit the requirements of all social groups, bolstering land markets and promoting economic stability.

Land and housing policy must include all elements of development, including economic, social, cultural, and human rights. Furthermore, the following five particular activities have direct and practical effects on general improvements in living and housing circumstances, as well as sound national policies for appropriate shelter and land access:

i. Encouraging fair access to land and housing resources; ii. Encouraging tenure security and property rights

iii. Preventing forced evictions and discrimination in the land and housing sectors, iv. Combating homelessness and landlessness while protecting the rights of homeless and landless persons, and v. Promoting access to legal, administrative, and other remedies for homeless and landless people.

In accordance with the foregoing, the following guidelines should be followed to ensure the LUA's efficacy and attainment of its objectives:

i. When implementing LUA, each state's governor should do so in a transparent and responsible way to all stakeholders.

ii. The Governor and Local Government should make every effort to minimize excessive delays in the processing of Certificate of Occupancy applications, their acceptance, and eventually the distribution of land to individuals.

iii. Because the purpose of Land Use is to provide access to land for possession, usage, and occupancy, the charge or fees should be decreased to encourage greater investment and land use in the country. This will aid in the growth of the economy.

iv. Appropriate compensation for landed assets or unexhausted improvements on land shall be provided to persons whose Rights of Occupancy are forcefully acquired. Compensation should be determined by open market value. v. A state-level Land Use Allocation Committee and a locallevel Land Use Advisory Committee should be created, with licensed Estate Surveyors and Valuers as members.

Planning the place of public involvement should be given pride of place in the process of land use policy formulation. At the outset of any land use strategy or program, this should include the development of an effective communication relationship with the public. The goal of citizen involvement should be to enlighten and educate the public about the planning process so that they may grasp the breadth and limitations of the process and choose alternative 


\section{International Journal of Engineering Applied Sciences and Technology, 2021 \\ Vol. 6, Issue 5, ISSN No. 2455-2143, Pages 207-219 \\ Published Online September 2021 in IJEAST (http://www.ijeast.com)}

policies that will benefit the community as a whole. A variety of answers to the protection of urban poor access to land, security of tenure, and city administration have been extensively recorded in the literature ( Dowall, 1991, Dowall and Giles, 1991; Azuila 1995; Zinimermann, 1998; Zevenhergen, 1998). The following recommendations are suggested, based on the aforementioned theoretical framework and findings in the subject area:

- Urban redevelopment or renewal with a human face/respect for human dignity, as evidenced by the adoption of the Katsina State of Nigeria strategy for urban redevelopment scheme (1999-2007), in which the people were involved from the scheme's conceptual stage to the end, when they were left in a better financial position by way of compensation than they were before the scheme, regardless of the type of title. It is also suggested that those who are involved in forced acquisition and land takings return home happy and satisfied.

- A large-scale registration and tenure upgrading and legitimization initiative in the study region will enhance living conditions and enable access to financial facilities.

- Strives to adapt land law to the situation and requirements of emerging cities, following the slogan "think globally, act locally."

- The presence of a dual, formal/informal, land distribution system is tolerated by public authorities (as it is in most Sub-Saharan African nations, notably Nigeria).

It is suggested that new settlements/new towns be built to coexist alongside the existing town, as is the case in most emerging country cities. In Adamawa State, Nigeria, for example, there is Jimeta-Yola, which houses the Government House/new settlement, and Yola Old Town, which holds the Palace of the 'Lamido of Adamawa'/indigenous settlement, primarily impoverished people.

- Establishing a streamlined registration system in which tenure may be gradually upgraded to actual rights based on the requirements and resources of individual families as well as the processing capability of the responsible administration.

- Adoption of Nuhu's (2008a) proposal for a paradigm shift in thinking and planning to address the issues of affordability, fairness, justice, and transparency in land tenure and city administration, as well as stakeholder participation.

- Reforms to the existing LUA in accordance with the current FG seven-point Agenda to empower the poor to participate actively in urban land choices, allowing them to escape poverty. Apart from implementing Nuhu's (2008b) proposal of creating norms and processes for obtaining tenure, land development, and delivering services that are accessible and cheap to the poor,

- Intensive public education of stakeholders on their anticipated responsibilities and involvement, as well as capacity training of employees involved in land administration and management to comply to good governance features/ICT compliance.

- To increase access to land justice, the government should improve and encourage the courts to be creative and inventive in land cases.

- The court should be encouraged to support faster hearings in land disputes in order to decrease the expense of litigation, which is otherwise complicated and beyond the ability of the average person.

\section{REFERENCES}

1) Barlowe, $R$ (1978), Land resource economics. Second edition. Englewood clifts N.J Prentice hall

2) Chileshe R.A., Tuladhar, A.M., (1995) A low cost approaches to land registration of customary lands: a case in Zambia, First Joint European Conference and Exhibition on Geographical Information, The Hague.

3) Denman, D.R. (1978). The place of Property: A New Recognition of the Function and From of Property Rights in Land. The Keep. Berkhamsted. Herts. Geographical Publication Ltd.

4) Deininger, K. (2005). "Land policy and Operations at the Bank: principle and Operational implications" World Bank.

5) Dowall, D.E. (1991), "Less is More: The benefits of minimal land development regulation" in Regularizing the Informal Land Development, 2: Discussion papers, US Agency for International Development, Office of Housing and Urban programmes, USAID, Washington, D.C.,PP9-20

6) Dowall, D.E. and Gilesa, C. (1991), "Urban Management and Land; A Framework for Reforming Urban Land Policies in Developing Countries", Urban Management Programmes policy paper 7, UMP, Washington, D.C.

7) Enemark S. and Sevatdal H. (1999): Being a paper presented at the UN-FIG Conference on Land Tenure and Cadastral Infrastructures for Sustainable Development, Melbourne, Australia 25-27 October.

8) Expert Group Meeting on Urban Indicator in 2002

9) Fortune-Ebie S.P.O. (2007), Land Rights and Secure Tenure as the Basis for economic empowerment and housing delivering: paper presented at the Stakeholders Forum organized by the Federal Ministry of Environment, Housing and Urban development at Rockview Hotel, Abuja, 6th -7th November 2007, p11.

10) Fortune-Ebie S.P.O. (2008), Keynote address presented at the Lagos International Housing Conference 2008 


\section{International Journal of Engineering Applied Sciences and Technology, 2021 \\ Vol. 6, Issue 5, ISSN No. 2455-2143, Pages 207-219 \\ Published Online September 2021 in IJEAST (http://www.ijeast.com)}

11) Government Notice No. 24, Vol.94 of 15th May, 2007 Official Gazette of Federal Republic of Nigeria (Provisional Results of Population Census, 2006)

12) Iro I. (2008), Welcome Address by the General Manager Abuja Geographic Information System (AGIS) Open-House Celebration, February 28.

13) Kakulu, I.I. (2007), The Assessment of Compensation in Compulsory Acquisition of Oil and Gas Bearing Lands: The Niger Delta experience.

http://www.tkk.fi/Yksikot/Kiinteisto/FIG/pdffiles/0 6092007Kakulu

14) Land Use Act Cap 202, Laws of the Federation of Nigeria, 1990.

15) Law Lord (2000) Land Use Act 1978 Published by Law Lord Publisher, Abuja.

16) Mabogunje, A.L. (1975). 'Prolegomenon to Urban Poverty in Nigeria"' in Poverty in Nigeriabeing the proceedings of the 1975 Annual Conference of the Nigerian Economic Society (NEC 1975).

17) Magel, H. (2006), FIG Presidents' opening address at the 5th FIG Regional Conference with the theme: Promoting Land Administration and Good Governance at Accra, Ghana, March 8th -11th 2006, p7.

18) Mulolwa, A., (2002), Integrated land delivery, towards improving land administration in Zambia, Delft University Press, Delft.

19) Munro-Faure, P. (1999) Presented at the UN-FIG Conference on Land Tenure and Cadastral Infrastructures for Sustainable Development, Melbourne, Australia 24-27 October 1999

20) Nuhu, M.B. (2006a), Analysis of Land Access and its Impact on the Urban Poor: The case of Minna Metropolis. Proceedings of the School of Environmental Technology (S.E.T) Federal University of Technology, Minna 1st Annual Conference with the theme: Rebuilding the Built Environment 28th February -2nd March, p194.

21) Nuhu, M.B. (2006b), Compulsory Acquisition and Compensation of Land in Federal Capital Territory, Abuja: A case study of University of Abuja permanent site. Environmental Technology and Science Journal (ETSJ) vol.1 No.1 Pp 109-110.

22) Nuhu, M.B. (2007b), Compulsory Purchase and Payment of Compensation in Nigeria: a case study of Federal Capital Territory (FCT) Abuja. Being paper presented at the Joint Seminar on Compulsory Purchase and Compensation in Land Acquisition and Takings, September 6th to 8th 2007, in Helsinki, Finland. Organized by FIG Commission 9 in co-operation with FIG Commissions 7 and 8, FAO's Land Tenure
Service, World Bank, and Helsinki University of Technology.

23) Nuhu, M.B. (2008a), Goodwill message at the Workshop with the theme: Land Administration and Management, at U.K Bello Arts Theatre, Minna, Nigeria, 11th -12th February, p2.

24) Nuhu, M.B. (2008b), Improvement of Tenure Security as Pro-poor Tool for Preserving the Housing Environment: a Nigerian case study. Being a paper presented at the Year 2008 SET-FUT Annual National Conference with the theme: Preserving the Environment, 27th - 29th February 2008.

25) Nuhu, M.B. (2008c), Good Governance in Land Tenure and Management of Nigerian Cities, being a paper presentation at the 38th Annual Conference of the Nigerian Institution of Estate Surveyors and Valuers (Abuja 2008) with the Theme: The Development and Management of Nigerian Cities; 08th to 13th April, 2008, Abuja.

26) Okolocha, C.H (1980)"The Evolution of a Land Policy in Nigeria," in Taylor, Current Trends in Urban Planning and Development in Nigeria.

27) Payne, G (2000), Urban Land Tenure Policy Options: Titles or Rights. A paper presented at World Bank Urban forum. Virginia

28) Platteau, J.P. (2000), Institutions, Social Norms, and Economic Development Harwood Academic Publishers.

29) UNCHS (1999), Implementing Habitat Agenda: Adequate Shelter for, All Global Campaign for secure Tenure, UNCHS, Nairobi

30) UN-ECE, (1996), Working paper on Land Administration Guidelines, UN publication, New York, Geneva.

31) UN/Habitat (2004) Pro-Poor Land Management, Nairobi, Kenya, P.8. United Nations Conference on Human Settlements [Habitat 1], held in Vancouver, May 31- June 11 1976, item 10 of the Conference Report

32) Van der Molen, P., Lemmen, C., (2004) Unconventional Approaches to Land Administration, a point of view of land registrars and land surveyors, proceeding of Expert Group Meeting FIG Commission 7, FIG, Frederiksberg.

33) Viitanen K. and Kakulu I.I. (2008) Global Concerns in Compulsory Purchase and Compensation Processes Integrating Generations FIG Working Week, Stockholm, Sweden June 1419 2008, p9

34) World Bank (1972), Urbanization; Sector working paper, World Bank Washington, D.C

35) World Bank, (1975). "Land policy Reform paper" World Bank, Washington D.C 
International Journal of Engineering Applied Sciences and Technology, 2021

Vol. 6, Issue 5, ISSN No. 2455-2143, Pages 207-219

Published Online September 2021 in IJEAST (http://www.ijeast.com)

36) World Bank Report, (2006). UN-HABITAT publication, 2006.

37) Yakubu, M.G (1985) Land Law in Nigeria McMillan Publishers, London PP 193-214 and Basnigstoke, Lord Lugard, Political Memoranda No. 10.

38) Zevenbergen, J (1998), "Is registration really the panacea for defective land administration in developing counties? "Proceedings of International conference on land Tenure conference on land Tenure in the Developing world, with a focus on South Africa, University of Cape Town, 27-28 January, pp570-580

39) Zimmermann, W (1998), "Facing the Challenge of implementing land policy- lessons learned in the context of intonation cooperation," proceeding of the international conference of Cape Town, 27-28 January, pp581-587. 